\title{
A meta-analysis of the impact of stocking rate on the productivity of pasture-based milk production systems
}

\author{
B. McCarthy ${ }^{1,2}$, L. Delaby ${ }^{3}$, K.M. Pierce ${ }^{2}$, F. Journot ${ }^{1}$, B. Horan ${ }^{1}$
}

${ }^{1}$ Teagasc, Moorepark Dairy Production Research Centre, Fermoy, Co.Cork, Ireland, ${ }^{2}$ School of Agriculture, Food Science \& Veterinary Medicine, UCD, Belfield, Dublin 4, Ireland, ${ }^{3}$ INRA, AgroCampus Ouest, UMR Production du Lait, SaintGilles, France

Email: brian.mccarthy@teagasc.ie

Introduction The abolition of milk quotas by 2014 will have a major influence on the Irish dairy industry with factors such as land, stock and labour availability constraining production in future years. Stocking rate (SR), expressed as cows per hectare (ha) is the major factor determining productivity from pasture and recent research by Macdonald et al. (2008) reported that an increase in SR results in an increase in milk production per ha but a decrease in milk production per cow. The objective of this study is to quantify the response in milk production per cow and per ha associated with a change in SR using meta-analysis techniques on experimental data from 1960 to 2008 . A meta-analysis is a quantitative review using scientific methods, based on statistics, to summarise previous research in a particular topic (Sauvant et al. 2008).

Materials and methods A thorough literature review of SR experiments resulted in the final database containing 44 papers and 109 experiments for analysis. For inclusion in the database, an experiment had to contain a comparison of at least two SR under the same experimental conditions. Experimental data included experiment length, grazing cow-days per ha, the various SR and milk production and bodyweight (BW) results per cow and per ha. As the objective of the meta-analysis was to analyse the effect of an increase in SR from a low level, the lowest SR treatment within each experiment was considered the base SR, with the milk production at this SR considered the base milk production performance. Large variability in animal BW was observed over both time and between experiments within the database, consequently each SR was also described in terms of an additional $100 \mathrm{~kg}$ BW per ha. For analytical purposes, two main subsets of data were created. In common experimental length (Type C) experiments, the experimental period was common to all SR treatments within the respective experiment with the effects observed due to differences in feed allowance over varying periods of time. In variable experimental length (Type V) experiments, the length of the experimental period varied between SR treatments (i.e. full lactation studies). A study effect (IdExp) representing the variance between studies not accounted for by the other variables in the model was included in each model as described by Sauvant et al. (2008). The independent variables actual and proportional change in milk production according to a change in SR were continuous in nature and analysed using linear mixed models using the statistical procedures software of SAS (Proc MIXED)with IdExp included as a random effect and an unstructured variance covariance structure (UN) among records.

Results Average SR and experimental length within the Type C database was 3.83 cows per ha and 168 days respectively. The average SR and experimental length within the Type V database was 2.8 cows per ha and 272 days respectively. An increase in SR of 1 cow per ha resulted in a decrease in daily milk yield per cow of 7.4 and $8.7 \%$ for Type C and V data respectively while milk yield per ha increased by 20.1 and $19.6 \%$, respectively (Table 1). Within the Type V dataset, a 1 cow per ha increase in SR also resulted in a $15.1 \%$ reduction in lactation length (equivalent to 42 days). Predicted milk production performance was also calculated using equations based on SR and BW per ha. Low residual standard errors indicated a good precision of the predictive equations with the exception of proportional change in milk production per cow.

Table 1 Change in milk production per cow and per hectare for an increase in stocking rate of 1 cow per hectare for common (Type C) and variable (Type V) experimental length data.

\begin{tabular}{|c|c|c|c|c|c|c|c|c|}
\hline \multirow[b]{3}{*}{ Performance per cow } & \multicolumn{4}{|c|}{ Type C } & \multicolumn{4}{|c|}{ Type V } \\
\hline & No. data & Base & Change & $\%$ change & No. data & Base & Change & $\%$ change \\
\hline & & & & & & & & \\
\hline Milk yield (kg) & 99 & 18.1 & -1.23 & -7.42 & 22 & 15.8 & -1.38 & -8.66 \\
\hline Milksolids ${ }^{1}$ yield $(\mathrm{kg})$ & 69 & 1.33 & -0.08 & -6.97 & 20 & 1.37 & -0.13 & -9.15 \\
\hline Performance per hectar & & & & & & & & \\
\hline Milk yield $(\mathrm{kg})$ & 99 & 8,868 & 1,657 & 20.1 & 22 & 9,878 & 1,568 & 19.6 \\
\hline Milksolids yield (kg) & 69 & 689 & 113 & 18.5 & 20 & 957 & 101 & 11.3 \\
\hline
\end{tabular}

${ }^{1}$ Milksolids $=$ fat + protein

Conclusion The results illustrate that whilst milk production per cow is reduced as SR increases, a strong positive relationship exists between SR and milk production per ha. The low predictability of proportional change in milk production per cow according to the classical SR definition of cows per ha suggests that SR would be more appropriately defined in terms of the change in available feed offered per animal within each treatment.

\section{References}

Macdonald, K.A., Penno J.W., Lancaster, J.A.S., and Roche, J.R. 2008. Journal of Dairy Science. 91, 2151-2163.

Sauvant, D., Schmidely, P., Daudin, J. J., and St-Pierre, N. R. 2008. Animal. 2, 1203-1214.

Statistical Institute. 2006. SAS Institute, Cary, NC, USA. 